\section{ARC-WELDERS' LUNG}

BY

\section{BERTRAM T. MANN, M.D., B.Sc., D.P.H. F.C.C.P.}

Consultant Chest Physician, Royal Halifax Infirmary AND

\section{EDMOND R. LECUTIER, M.B., Ch.B., F.R.C.S.} Consultant Thoracic Surgeon, Bradford Royal Infirmary

Arc welding is an important and expanding technique used in many branches of the engineering and shipbuilding industries. The equipment employed consists of covered electrodes with a core of metal and a heavy cellulose or mineral coating. At the high temperature $\left(1,500^{\circ}\right.$ C. $)$ generated during welding operations the metal core and flux of the two electrodes spread over the welded metal. The greyish-white vapour which arises during operations has been shown to consist of oxides of iron, calcium, sodium, lead, aluminium, manganese, tin, cadmium, copper, titanium, magnesium, and silica, as well as nitrogen peroxide, ozone, etc. It is the inhalation of these fumes which produces the radiological changes in the chest of arc welders, first described by Doig and McLaughlin in 1936.

During the past twenty years a number of workers in Britain (Doig, 1949), Germany (Koelsch, 1941 ; Humperdinck, 1942), Belgium (Mignolet, 1950), and the U.S.A. (Nayer, 1942) have observed abnormal $x$-ray patterns, usually taking the form of a deposition of fine nodules (Sander, 1944 ; Sutherland and Fawcitt, 1945), in the lungs of welders. Some authors (Collen et al., 1944 ; Collen, 1947; Doig, 1949, 1954) have expressed the view that there is no statistical evidence to suggest any special hazards in this occupation, that the radiological changes are reversible (Britton and Walsh, 1940), and that such workers are asymptomatic. In consequence the impression has gained currency that the iron oxide fumes are inert (Doig and McLaughlin, 1936, 1948 ; Groh, 1944), and that the radiological findings are benign (Enzer et al., 1945 ; Pendergrass and Leopold, 1945 ; British Medical Journal, 1948 ; Wyers, 1949 ; Poinso et al., 1953). Oddly enough, there is very little pathological evidence (Enzer and Sander, 1938 ; Charr, 1955) to uphold this view of the complete innocence of arc-welders' lung.

The following case should ensure a fresh appraisal of the medical problems associated with this occupation.

\section{Case Report}

The patient, aged 49, had been employed as an arc welder for over 25 years. The dimensions of the shop in which he was engaged were 50 by $30 \mathrm{ft}$. (15 by 9 metres). Seven other welders worked in the same room and the ventilation was unsatisfactory. The patient was provided with an arcwelders' screen, which gave protection from the glare and heat, but had never used any form of respirator. The electrodes were of mild steel, although the covering was a proprietary preparation containing ? asbestos and silica. The work consisted mainly of welding boilers. At no time did the patient engage in fettling, though his work involved cleaning the welded slag with a wire brush.

On leaving school he spent six years as a jewellery salesman, and since then his only occupation has been arc welding. His personal and family health was good, although during the previous 18 months he was short of breath on exertion and on going up inclines. He complained of slight cough and mucoid sputum. His appetite was good and his weight constant.

Clinically, nothing of note was detectable on pulmonary or cardiovascular examination. $\mathrm{He}$ was Mantoux-positive to 1:100 O.T.; E.S.R., $2 \mathrm{~mm}$. per hour. Radiologically there was an increase in vascular markings, accompanied by a fine stippling of nodules $1 \mathrm{~mm}$. in size, scattered mainly throughout the lower two-thirds of both lung fields. These micro-nodules were uniform in density, were discrete, and showed little tendency to merge into the pulmonary vascular background. An opacity 3 by $1.5 \mathrm{~cm}$. was found in the apical segment of the right upper lobe. The patient was admitted to hospital for investigation.

A tomogram of the opacity showed it to be nonhomogeneous. Maximal voluntary ventilation and timed vital capacity were about $70 \%$ of their predicted values. Fifteen sputa were negative for acid-fast bacilli on direct smear and culture.

A diagnosis of right apical pulmonary tuberculosis associated with arc-welders' lung was made.

Operation.-Right upper lobectomy was performed on April 16, 1956. At operation the lung had an unusual "feel " like pitting oedema, and there was a noticeable lack of tissue retraction on expiration. The lobe was immediately prepared by the Gough and Wentworth technique.

Histological Examination.-Large sections were cut and stained by Perls's method for iron pigment. Professor Gough reports: "In the lower part of the lobe the emphysema is of the focal type related to the dust, but in the upper part it has become confluent with whole lobules involved in the lesion. The granuloma is presumably tuberculous, modified by the iron dust, as so often happens with benign pneumoconiosis. From the large sections it is not possible to determine how much of the iron is exogenous and how much from the body, but, undoubtedly, a good deal of the iron is from the inhaled dust."

Histological examination revealed the presence of pneumoconiotic bodies, which were quite as marked as those to be observed in asbestosis. These deposits appear to be similar to those described by Schilling (1956) in byssinosis, but, whereas in cotton disease the bodies are round or oval, the striking feature in arc-welders' lung is the large size and complexity of the bodies. Professor Gough, in a personal communication, reports that "the appearances indicate that the dust is one to which the body is reacting, so that the dust cannot be regarded as inert."

Petrological Analysis.-Incineration of a large section revealed that the material was partly combustible, the residue consisting of a dark-brown material due to the presence of iron oxide.

Chemical analysis of the lung tissue for iron was performed by Dr. Nagelschmidt, of Sheffield. The emphysematous portion had $22 \% \mathrm{Fe}_{2} \mathrm{O}_{3}$ and the tuberculous portion $13 \% \mathrm{Fe}_{2} \mathrm{O}_{3}$. This amounts to $4.2 \%$ dry lung for the first and $1.6 \%$ for the second sample. Thus it would appear that the iron content of this patient's lungs is at least 100

\begin{tabular}{|c|c|c|c|c|c|c|c|c|c|c|c|c|c|c|}
\hline \multicolumn{15}{|c|}{ Spectrochemical Analysis (g.\%) } \\
\hline Portion of Lung & $\mathrm{CaO}$ & $\mathrm{Na}_{2} \mathrm{O}$ & PbO & $\mathrm{Fe}_{2} \mathrm{O}_{3}$ & $\mathrm{Al}_{2} \mathrm{O}_{\mathbf{3}}$ & $\mathrm{Mn}_{3} \mathrm{O}_{2}$ & $\mathrm{SnO}$ & $\mathrm{CdO}$ & $\mathrm{CuO}$ & $\mathrm{TiO}_{2}$ & MgO & $\mathrm{SiO}_{2}$ & $\mathrm{~B}_{2} \mathrm{O}_{3}$ & $\begin{array}{c}\mathrm{Bi}, \mathrm{Sb}, \mathrm{As}, \mathrm{NiO}, \\
\mathrm{Ag}_{2} \mathrm{O}, \mathrm{ZnO}_{\mathrm{nO}} \\
\mathrm{Co}_{3} \mathrm{O}_{4}, \mathrm{Cr}_{2} \mathrm{O}_{3}\end{array}$ \\
\hline $\begin{array}{l}\text { Emphysematous part dried lung } \\
\text { Ashed emphysematous lung .. } \\
\text { Tuberculous part of lung } \ldots \\
\text { Ashed tuberculous part of lung }\end{array}$ & $\begin{array}{l}0.02 \\
0.05 \\
0.02 \\
0.02\end{array}$ & $\begin{array}{r}0.02 \\
>2 \cdot 5 \\
0 \cdot 2 \\
>2 \cdot 5\end{array}$ & $\begin{array}{r}0.025 \\
0.1 \\
<0.025 \\
0.05\end{array}$ & $\begin{array}{c}2.0 \\
>2.0 * \\
2.0 \\
2.0\end{array}$ & $\begin{array}{r}0.3 \\
>1.0 \\
0.3 \\
0.3\end{array}$ & $\begin{array}{l}0.04 \\
0.1 \\
0.02 \\
0.02\end{array}$ & $\begin{array}{l}0.02 \\
0.1 \\
0.01 \\
0.02\end{array}$ & $\begin{array}{l}0.01 \\
0.04 \\
0.01 \\
0.01\end{array}$ & $\begin{array}{r}<0.005 \\
0.005 \\
<0.005 \\
0.005\end{array}$ & $\begin{array}{l}0 \cdot 2 \\
0 \cdot 5 \\
0 \cdot 5 \\
0 \cdot 2\end{array}$ & $\begin{array}{l}0.02 \\
0.05 \\
0.02 \\
0.01\end{array}$ & $\begin{array}{l}0 \cdot 05 \\
0 \cdot 1 \\
0 \cdot 1 \\
0 \cdot 1\end{array}$ & $\begin{array}{l}<0.01 \\
<0.01 \\
<0.01 \\
<0.01\end{array}$ & $\begin{array}{l}\text { No indication } \\
" " \quad " \\
", \quad "\end{array}$ \\
\hline
\end{tabular}

It will be noted that both the emphysematous and the tuberculous portions of lung have a very high iron content. The remarkably high iron content found in the emphysematous portion of ashed lung $\left(^{*}\right)$ is interesting and strongly supports the results of chemical analysis reported above. 
times greater than normal values (Rechenberger and Schairer, 1947). Spectrochemical analysis of four samples of lung ash was kindly carried out by the Bragg Laboratory, Sheffield, with the results shown in the Table.

\section{Discussion}

Arc-welders' lung arises because of inhalation of the smoke and fume of iron oxide. It is the high temperature of the arc which produces the oxidation of the iron. After the inhalation of these tiny particles, $1 \mu$ in size, into the lung alveoli they are arrested in the peribronchial and perivascular lymphatics, and in lymph nodules, and it is this deposition of tiny radio-opaque iron particles which gives the characteristic $x$-ray appearance.

Our patient, though suffering from only cough and shortness of breath, showed evidence of considerable focal and lobular emphysema, a marked loss of lung elasticity on thoracotomy, and a maximum voluntary ventilation and a timed vital capacity of about $70 \%$ of their predicted values.

In the past the general consensus of opinion has been that the condition of arc-welders' lung is benign and innocent. This view has been based on the frequent clearing of miliary radiological shadows in the chest $x$-ray picture, and on the absence of major pulmonary symptoms. Indeed, this also has been our own experience in the past. However, it may well be that prolonged exposure to iron fume (in this case over 25 years) in an enclosed space with little or no protection from the fumes does produce secondary emphysematous changes which are considerable and permanent, and are responsible for the irreversible lung damage reported in this patient.

\section{Summary}

A cases is recorded of arc-welders' lung in association with a tuberculoma, in a man engaged in arc welding for over 25 years.

Radiologically an increase in the pulmonary vascular pattern, with micro-nodular shadows, mainly concentrated in the lower two-thirds of the lung fields, was observed.

At operation a distinct loss of lung elasticity was noted, and this was confirmed by respiratory physiological investigation. The pathological appearances of the excised lobe, in addition to the deposition of iron, revealed a considerable degree of emphysema. Chemical and spectrochemical analyses show the lung to have an iron content at least 100 times greater than normal values. Evidence strongly suggests that arc-welders' lung is not always the innocent or reversible condition which has been suggested by all previous workers.

We wish to record our grateful appreciation to Professor J. Gough for his kindness in cutting and preparing the sections, and for his advice in reporting on the histological specimens; also to Dr. Nagelschmidt for the chemical and petrological analysis of the sections.

\section{BIBLIOGRAPHY}

British Medical Journal, 1948, 1, 1088

Britton, J. A., and Walsh, E. L. (1940). J. tndustr. Hyg. 22, 142 Collen, M. F., Dybdahl, G. L., and O'Brien, G. F. (1944). Ibid., 26, 1. Charr (1947). Ibid., 29, 113.

Charr, R. Rev. Tuberc., 71, 878.

Doig, A T. (1954). In E. R. A. Merewether's Industrial Medicine and Hygiene, 3, 125. Butterworth, London.

- and McLaughlin, A. I. G. (1936). Lancet, 1, 771

Enzer $N$ (1948), Ibid., 1, 789

Enzer, N., and Sander, O.' A. (1938). J. industr. Hyg., $20,333$.

Groh, J. A. (1944). Industr. Med. Surg., 13, 601.

Humperdinck, K. (1942). Disch. med. Wschr., 68, 17.

Koelsch, F. (1941). Arch. Gewerbepath. Gewerbehyg., 10, 519.

Mignolet, F. (1950). Arch. belges méd. soc., 8, 513.

Nayer, H. R. (1942). J. Amer. med. Ass., 119, 1501

Pendergrass, E. P., and Leopold, S. S. (1945). Ibid., 127, 705.

Poinso, R., Rouyer, P., and Jouve, G. (1953). Arch. Mal. prof., 14, 479.

Rechenberger, J., and S̈chairer, E. (1947). Z. ges. exp. Med., 112, 559.

Sander, O. A. (1944). J. industr. Hyg., 26, 80

Schilling, R. S. F. (1956). Lancet, 2, 261, 318.

Sutherland, C. L., and Fawcitt, R. (1945). Proc. roy. Soc. Med., 38, 519.
Wyers, H. (1949). Postgrad. med. J., 25, 632.

\section{FRACTURE OF NECK OF FEMUR SURVIVAL AND CONTRALATERAL FRACTURE}

BY

I. M. STEWART, M.B., F.R.C.S.Ed.

Clinical Research Assistant, Eastern Region (Scotland)

Orthopaedic Service

As a consequence of the increased proportion of aged in the population fractures in the elderly are more frequent. The classical example, fracture of the neck of the femur, continues to pose new problems. The following survey indicates fresh implications of this common injury.

During the four years from 1952388 patients have been studied. The initial two-year period has already been reported (Stewart, 1955). In that paper the first absolute incidence was recorded. The present report is a sequel occasioned by a fresh problem-namely, the readmission of significant numbers of patients with a second fracture of the same variety on the opposite side.

\section{Present Series}

The series represents the total unselected incidence of fractures of the neck of the femur in one area. No patient was refused admission. A standard routine of management was practised throughout. Surgical treatment was given to $95 \%$ of the cases. After internal fixation the patients were encouraged in immediate mobilization, but weight-bearing was prohibited until there was evidence of bony union.

In the period under review 27 patients sustained the fracture, first on one side and then on the other (see Table). The contralateral fracture followed return to activity and, with one exception, did not occur spontaneously during confinement to bed or chair. It seemed to be a consequence of non-weight-bearing, and occurred only when weight was again borne freely. The interval between fractures in 24 patients varied from a few months to ten years, with the majority close to the average of two years and a few months. This is also about the time taken to regain the degree of activity which determined the original fracture. Reactive remodelling of bone declines with age (Lacroix, 1951), and the elderly patient may not respond rapidly enough to the stimulus of resuming walking. As with stress fractures in general, this particular fracture results from the repeated application of a strain with a rapidity which outstrips the capacity for reactive remodelling by the bone. Characteristically, force is absent from the production of the injury.

There is further evidence, as shown by the symmetry of the bilateral cases, that the final dissolution of the bone has simply occurred at its weakest point. The two exceptions (Cases 5 and 8) may merely prove the rule. Less obvious is the reason why the right hip was the first to prove unequal to demands in a similar proportion. It has been said, in relation to other mechanical failings of the weight-bearing skeleton, that this is a "right-footed world" (Goff, 1954). The precedence of right before left may be no more than the result of "best foot foremost" in the conflict with gravity. The femoral neck becomes so vulnerable that the most trivial factor may tip the balance to either side.

\section{Discussion}

Solution of continuity in the neck of the femur can certainly follow disuse. Restrictions imposed by the first fracture, and ageing physique, deprive the weight-bearing bones of the stresses normally expressed by the cancellous architecture of the femoral neck in accordance with Wolff's law. Fractures of the neck of the femur are a not infrequent spontaneous occurrence in bedfast or paralytic patients. This is exemplified in the case of a male who complained of hip pain while incompletely confined to bed in hospital 